\title{
Application on Humanism Education Thought in College English Teaching \\ Xueqin $\mathrm{Li}$
}

Teaching and Research Institute of Foreign Languages, Bohai University, Jinzhou, 121013, China

284554744@qq.com

Keywords: humanism education thought; college English teaching; application; measure

\begin{abstract}
Integrate humanistic ideas into college English teaching is conducive to improve the efficiency of English teaching, improve students' understanding of humanity, shape students' ideal personality, make students better realize their own value. Analysis in this paper, based on the humanism education thought, carry out the necessity of humanistic education in college English teaching, puts forward the ideas of humanism education in college English teaching in the application of specific measures. Measures include: correctly understand the relationship between humanistic education and English teaching, improve English teachers' humanistic literacy, cultivate students' concept of humanistic education, improve the humanistic information infusion validity, expand the cultural background knowledge in the teaching material, change students' state of mind, to carry out a variety of the second classroom activities.
\end{abstract}

\section{Introduction}

Humanistic education is to promote educatees' realm of human ascension, and individual and social value realization of ideal personality education, the essence is the human nature education, humanistic spirit core is self-restraint. This kind of spirit to develop general through multiple channels, including extensive cultural knowledge nourishing, elegant cultural atmosphere edify, excellent cultural tradition edify and profound life experience, etc. This education attach importance to both outside-in culture form, more emphasis on the self-understanding and interpret the mind. At the end of the day, to make people understand and pay attention to the meaning of life, and more humanistic care to the society, fundamentally embodies the essence of education and the ideal.

Higher education is going to cultivate the high-quality talents of background then must to integrate science education and humanities education, the organic combination of the discipline curriculum teaching, the implementation of the vicissitudes, discipline penetration, humanity quality education, to cultivate harmonious all-round development of people. To humanistic education into college English teaching, not only promote English learning, improve teaching efficiency, and good for students to play personality and potential, to improve the knowledge and skills of English, to meet the requirements of the future society for foreign language; At the same time, also has a good sense of self and the tutelage, has the active service consciousness and ability of the society, knowledge, ability and character. These people to the society in the future, with a strong charisma and exemplary role, potential quality for improving social atmosphere and improve the quality all play an important role. Therefore, this study has profound practical significance.

\section{Humanism Education Thought}

Humanism education is the European Renaissance emerging bourgeois thinkers advocated by the new culture and new ideas. In different stage of development, humanistic education thoughts have different thoughts. The modern humanism education thought is in the prevalence of 60-70s of the 20th century in the United States of a kind of education thoughts, adhering to the western long tradition of humanism education, pay attention to the value orientation of education object and perfect personality, at the same time, the teacher is teaching cultural knowledge to promote the harmonious development of personality, emphasis on training people should pay attention to integrity, comprehensive and creative [1, 2]. 
Modern humanism education thought has two characteristics: first, pay attention to "self-realization" of the individual, humanism education attaches great importance to the education thought the role of in the process of cultivating people, emphasizes the cultivation of body and mind harmonious development of both the "new man". Education must start with the formation of "the perfect humanity" and "full development" the potential of people as the ultimate goal, namely "self-actualization". Think a self-fulfilling should be on the personality characteristics reflect the person's integrity and creativity; Second, emphasis on the expansion of the school teaching content, decided the education content, the purpose of education of modern humanism education content focus on meet the needs of the learners' personality traits and the overall harmonious development. Elastic on the course arrangement, pay attention to the ideological content of the course content and affective mutual penetration, request the arrangement of course content to students as the center, to consider for students of different ability to provide appropriate courses. Give full consideration to the individual differences of students, students can be divided into different levels to the corresponding education, make each student's potential is maximum.

Modern humanism education thought advocating inspire and train students' correct value orientation in the education, the students to have ideal and moral man, this also obeys the law of people's development. When a person walks into society with a nature and become a member of the society, the survival of the pillar is more reflected in the value of living. People's influence on the surroundings and social evaluation of individual more depends on the value of life, and everyone's code of conduct are necessarily good morals as the fundamental, rise to positive role to the society on the basis. Humanism education thought is to advocate culture have positive significance for society, it is the advanced nature of humanism education thought.

\section{Necessity on Humanism Education Thought in College English Teaching}

Foreign language education is the essence of humanistic spirit and the humanities education, foreign language education in quality education plays a personality cultivation and the basic role of culture, from the foreign language the teaching content of inclusion, almost includes many aspects, such as people's thinking and behavior. The goal of learning English will not only master the language knowledge, but also to cultivate and improve the students' humanities accomplishment, promote the all-round development of students. Therefore, to carry out the humanistic education in college English teaching is very necessary.

(1) Carry out the humanistic education is the college English curriculum teaching requirements. The distribution of the ministry of education of the college English curriculum requirements , points out that the institutions of higher learning should be according to the actual situation, according to the college English teaching goal design out their college English course system, the comprehensive English, language skills, language application, language and culture and professional required courses and elective courses, such as English class, the organic combination, to ensure that students of different levels in English application ability are fully trained and improved. College English course is not only a language foundation, and broaden the knowledge, understand world culture quality education courses, both instrumental and humanism. Therefore, the design of college English course should also give full consideration to the students' cultural quality education and the cultural knowledge teaching.

(2) Carry out the humanistic education is the objective requirement of quality education. The ministry of education issued several opinions on strengthening college students' cultural quality education, points out that strengthening cultural quality education, to promote the education thought and education idea transformation, promote higher school personnel training mode, curriculum system and teaching content reform, cultivating high quality talents to satisfy the needs of the 21st century, is of great significance. Work to strengthen the cultural quality education is the focus of the humanistic quality education, strengthening of students, such as literature, history, philosophy and art education in the humanities and social sciences, as well as the liberal arts students to strengthen the education of natural science, in order to improve the students' cultural quality, aesthetic temperament and interest, the humanities and scientific quality. 
(3) Carry out the humanistic education is the realistic requirement of international communication. Increasingly wide range of international communication, foreign language become the key to the world, opened its doors to the required foreign language talents in the new period, should not only possess solid language the basic skills, have good of accomplishment and character; Not only to the western culture is full of yearning, should see more profound Oriental culture; In the mastery of language knowledge itself value at the same time, more should have when applying knowledge of conscience and sense of responsibility and values. To achieve this there are both professional knowledge and ability accomplishment, it is necessary to understand the culture behind the language, to understand foreign customs and habits and historical traditions, the Chinese and western cultural essence of the comparative study of the moderns, made the learning of the language knowledge internalizes the humanities accomplishment and nourish the spirit, so as to really get the self-improvement and development.

(4) Carry out the humanistic education is the need of complex talent training [3, 4]. Inter-disciplinary talents refer to the knowledge and ability of the composite. Humanities education focuses on the teaching and learning of knowledge, and compound talent training can promote the improvement of ability. Light it is common in colleges and universities intellectual ability, students' emotional, aesthetic, self-care ability and social cooperation, cultural training is often neglected, resulting in a decline in students feeling ability and aesthetic ability is low, the lack of curiosity and exploratory, lack of a sense of accomplishment and pride to experience, the lack of affection experience of human nature, etc., these are all related to neglect humanities education. Humanistic education to students has the following functions: one is that let students understand human culture directly, especially the national culture; Second is to let the student at the same time from two aspects of scientific value and humanistic value. To think and treat our activities of science and technology; three is, the humanities knowledge may also make students more full of passion and imagination.

\section{Concrete Measures on Humanism Education Thought in College English Teaching}

According to the characteristics of the college English teaching and practical teaching experience, this paper combined with the related references [5-8], this paper put forward the ideas of humanism education in college English teaching of the application of specific measures are as follows:

(1) Understanding humanistic education and the relationship of English teaching correctly. English language teaching and humanistic quality cultivation is inseparable. Many teachers of English language teaching and the relationship of humanistic education understanding fuzzy, simply think that learning English is a kind of language learning and teaching is to cultivate the students' language knowledge and language application ability. Also has the teacher that cultural awareness is the cultural knowledge, the purpose of teaching is to improve student performance, instead of improving the students' humanistic quality and consciousness of the world. The main cause of this situation is affected by the traditional linguistics theory and the theory of English teaching, and also related to China's exam-oriented education. College English teachers must know clearly the relationship between language teaching and cultural education in English teaching according to the modern English teaching philosophy, really understand the meaning and function of humanistic education in English teaching.

(2) Improve college English teachers' cultural literacy. Foreign language teachers are the language and culture, social function and cognitive function of language to make it work is a humanistic, the particularity of teachers' work content requirements of college English teachers must have rich knowledge of humanities and humanity quality. First, teachers should set up the idea of humanistic education in English teaching, the "life" education in the "to do" education, make the student learns "life" through "do things"; Second, strengthen the discipline of teachers education in the humanities education consciousness and ability. To encourage English teachers across the field, in the relevant areas of the humanities education, improve their general qualities. Finally, the teacher also should have good professional ethics, in the teaching process, should not only impart science knowledge, but also to teach moral, behavior standard and rule of human civilization. 
(3) Cultivate the students' humanistic education idea. A person's knowledge is not the inherent ideological system, was formed in the process of slowly growing. As a result, the students' humanistic ideas need gradually develop in the process of education. College English teachers in classroom teaching process must see essence through phenomenon and dig knowledge contains the humanistic feelings. Through classroom education humanistic ideas, cultivate the students' cultural consciousness. Can also hold some knowledge about the big discussion in the classroom, through the exchange of ideas between students to promote the humanities knowledge, enhance the students' humanistic ideas. To guide students to use English in your life, using a variety of methods for English study, social life is the source of culture, improve the students' culture and inner quality, must use various methods to stimulate students' learning desire, sets up the humanist education idea.

(4) Update the teaching means to improve the humanities information infusion validity. Colleges and universities should with multimedia and network technology as the means, and other advanced teaching implementation of humanistic education. In front of the teaching of multimedia courseware, put the related cultural content of the courseware, to raise the level of teachers' teaching technology, make full use of the electronic and image information, increase teaching information, cultivate the students' cultural awareness, improve humanities information infusion validity. Network is an important means of access to information, the main input channel is also learning. Teachers should according to the content of the cultural learning, collect and organize students like audio and video materials, arrange students to search on the Internet related topics at the same time, make relevant courseware, all-round and multi-angle understanding cultural connotation, let the students in the process of search data and make courseware subtly accept English culture, improve the humanistic quality.

(5) Expand cultural background knowledge in the teaching material. Let the student in the teaching of knowledge has a comprehensive understanding to the teaching material, especially involved in extra-curricular knowledge, including the social background, values, aesthetic consciousness and customs, culture, etc., must carry on the detailed explanation, to expand students' knowledge. For rich in deep meaning of the text, to focus on, guide students to independent thinking, to enrich their own emotional world, set up the correct outlook on life and values. Teaching process to guide students, let students to think about Chinese cultural symbols, around the discussion of Chinese culture, guide students to find the profound significance of Chinese national culture, so that the students in the understanding of foreign culture at the same time, also have a comprehensive understanding about Chinese culture, the spread of cultural inheritance. In college English text into human resources, improve the students' independent thinking ability and interest in English learning.

(6) Change students state of mind make humanistic teaching more targeted. First of all, to find and confirm the humanistic qualities of the students lost points, understand the students current ideological trends and classification analysis, to determine the direction of education; Then, the role of the students in the classroom, break the traditional teacher-centered pattern, causes the student to become the subject of the class change the passive state of mind to active status, actively participate in classroom teaching, change "want me to learn" to "I want to learn", bold question, opinions; Finally, give play to the role of teachers in the classroom. For students to ask questions, analysis, discussion, inductive summary, trains the student to use creative thinking to the habit of independent thinking, change passive accept to actively participate in, "knowledge" to "inspired by innovation".

(7) Carry out a variety of the second classroom activities. The second classroom to expand the channels of humanity quality education, improve the humanistic quality education effect. Teachers in English classroom teaching, to create a variety of opportunities to interact with students from the student's actual condition, the paper improve the students' humanistic quality, guide students to adapt to the way of the society. The second classroom activities need not constrained at the campus, lets the student out of the campus and social practice, it is also an effective way to test and improve humanistic quality. Social practice is a supplement to the classroom teaching and deepening, is an important way to study English. In under the guidance of teachers and students in order to improve 
the social practice ability as the goal, through extracurricular activities team or the English corner, English association, use a variety of activities to understand western etiquette and culture, through the rich and colorful activities, improve the interest in learning English.

\section{Conclusion}

The essence of education is teaching, humanistic education in college English teaching embodies the essential requirement of education. Humanistic education in college English teaching, improve students' humanistic quality education concept, has aroused people's more and more attention. Language is the carrier of culture, has the rich humanities connotation. College English is an important part of education, university course is one of the compulsory course of university undergraduate course education, all university students must learn English. English besides has the profound historical culture foundation, also is a blend of different national culture spirit, many countries is the bridge of cultural exchange. How to carry on the humanistic education in college English teaching is the college English education workers must explore [9]. In this paper, the successful application of specific measures, can improve the efficiency of college English teaching, open students' mind and soul, promote students' humanity realm, students' ideal personality, make students better realize their own value.

\section{Acknowledgement}

This work is supported by 2012 annual "Twelfth Five Year" planning project of Liaoning education science (JG12DB214).

\section{References}

[1] X. Tian, "On carrying out humanism education thought in English teaching," Education Exploration, vol. 33, no. 6, pp. 59-60, 2013.

[2] T. D. Liu, "The connotation, progress and practical significance of humanism education thought," Inner Mongolian Petrochemical Industry, vol. 30, no. 4, pp. 61-62, 2004.

[3] X. L. Yang, "Based on humanities education, training compound talents for development, construction of practical teaching system for English majors," Journal of Heilongjiang College of Education, vol. 31, no. 11, pp. 175-177, 2012.

[4] R. F. Luo, "Strengthening humanistic quality education in Higher Vocational colleges, To cultivate the compound talents with harmonious development," Journal of Hubei Radio \& Television University, vol. 29, no. 7, pp. 20-21, 2009.

[5] Y. S. Xue, "A study on the countermeasures of humanistic education in English teaching in senior high school," Journal of Xingtai University, vol. 31, no. 1, pp. 184-187, 2016.

[6] X. H. Wu, Y. H. Qin, "Exploration of humanistic quality education in College English Teaching," Journal of Hetao College, vol. 12, no. 4, pp. 61-63, 2015.

[7] M. Xiao, "On the Roles and Ways of Humanistic Education in English Teaching of Vocational colleges," Journal of Shanxi Institute of Economic Management, vol. 23, no. 1, pp. 93-95, 2015.

[8] R. Ye, "The feasibility and the way for penetration of humanity quality education in higher vocational English teaching," Journal of Jiamusi Vocational Institute, vol. 22, no. 5, pp. 10-11, 2015.

[9] J. F. Xiao, "Humanistic education in college English teaching," Journal of Chongqing University of Science and Technology (Social Sciences Edition), vol. 12, no. 2, pp. 125-126, 2015. 